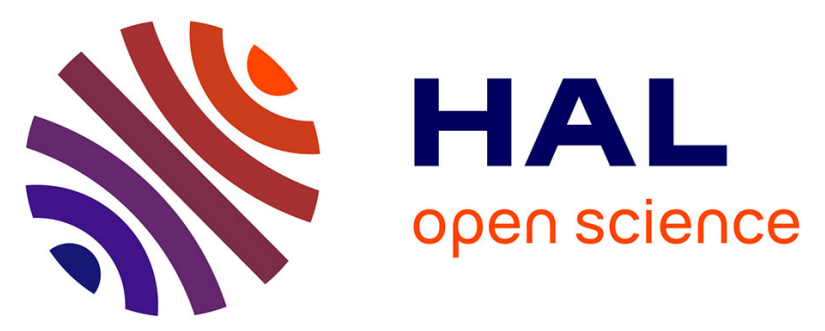

\title{
Epicormic ontogeny on Quercus petraea trunks and thinning effects quantified with the epicormic composition
}

Francis Colin, Rania Mechergui, Jean-François Dhôte, Florence Fontaine

\section{- To cite this version:}

Francis Colin, Rania Mechergui, Jean-François Dhôte, Florence Fontaine. Epicormic ontogeny on Quercus petraea trunks and thinning effects quantified with the epicormic composition. Annals of Forest Science, 2010, 67 (8), 10.1051/forest/2010049 . hal-00883636

\section{HAL Id: hal-00883636 https://hal.science/hal-00883636}

Submitted on 1 Jan 2010

HAL is a multi-disciplinary open access archive for the deposit and dissemination of scientific research documents, whether they are published or not. The documents may come from teaching and research institutions in France or abroad, or from public or private research centers.
L'archive ouverte pluridisciplinaire HAL, est destinée au dépôt et à la diffusion de documents scientifiques de niveau recherche, publiés ou non, émanant des établissements d'enseignement et de recherche français ou étrangers, des laboratoires publics ou privés.

$$
\text { Copyright }
$$




\title{
Epicormic ontogeny on Quercus petraea trunks and thinning effects quantified with the epicormic composition
}

\author{
${\text { Francis } \text { COLIN }^{1 *} \text {, Rania MECHERGUI }}^{1}$, Jean-François DHôTE ${ }^{2}$, Florence FonTAINE $^{3}$ \\ ${ }^{1}$ UMR 1092 INRA-ENGREF “Laboratoire des Ressources Forêt-Bois” INRA-Nancy, 54280 Champenoux, France \\ ${ }^{2}$ Département Recherche, Office National des Forêts, Direction Technique et Commerciale Bois, Boulevard de Constance, \\ 77300 Fontainebleau, France \\ ${ }^{3}$ Université de Reims Champagne-Ardenne, UFR Sciences, Laboratoire SDRP, Moulin de la Housse, B.P. 1039, 51687 Reims Cedex 2, France
}

(Received 16 November 2009; accepted 23 March 2010)

Keywords:

epicormic buds /

epicormic shoots /

bud cluster /

Quercus petraea

\begin{abstract}
- Effects of thinning on epicormics have rarely been demonstrated especially due to inaccurate surveying methods.

- Our objective was to assess the effect of contrasted thinnings on the ontogeny of epicormics on sessile oak. We used the epicormic composition defined as the arrangement of epicormics in different classes (isolated bud, clustered buds, short and long shoots and "picots") and quantified by the total frequency of epicormics and the proportion of each class.

- Epicormic composition was recorded in a silvicultural experiment testing highly contrasted thinnings, at 3 different stand stages and on lower $(0.5-3 \mathrm{~m})$ and upper $(3-6 \mathrm{~m})$ boles. Ageing provoked an accumulation of bud clusters and of picots. After thinning, epicormic shoots emerged mainly from (1) still present short epicormic shoots, (2) buds either isolated or in clusters depending on the stand stage. Upper boles bore epicormic compositions close to those observed on lower boles in the few preceding years. Upper logs were more reactive than lower boles.

- To conclude, the epicormic composition was a relevant tool to follow the dynamics of the epicormic ontogeny and to demonstrate the effects of thinning on it.
\end{abstract}

\section{INTRODUCTION}

Since the initial descriptions completed by Hartig (1878), epicormics have received much attention due to their impact on wood quality (Fontaine et al., 2004; Meadows and Burkhardt, 2001; Stubbs, 1986). Recently their contribution has been highlighted in tree development (Bryan and Lanner, 1981; Burrows et al., 2003; Edelin, 1977; Ishii et al., 2002) mainly through adjustment of leaf areas to environmental availabilities and in ecology (Belligham and Sparrow, 2000) mainly through repairing processes and vegetative regeneration. Epicormic shoots, sometimes called reiterates (Barthélémy and Caraglio, 2007), have been the most studied epicormics in both angiosperms (Colin et al., 2008; Fontaine et al., 2004; Nicolini et al., 2001; Spiecker, 1991) and gymnosperms (Bryan and Lanner, 1981; Edelin, 1977; Ishii et al., 2002; O'Hara and Berrill, 2009), in temperate (Del Tredici, 2001; Fink, 1980; Spiecker, 1991; Nicolini et al., 2001) as well as in tropical regions (Ashton et al., 1990; Fink, 1983; Nicolini et al., 2003). Epicormic shoots develop from latent buds (Hartig, 1878), also called epicormic buds, of proven-

* Corresponding author: colin@nancy.inra.fr titious (Burrows et al., 2008) or adventitious origin (Fink, 1983; Kauppi and Rinne, 1987). Besides buds and shoots, epicormics include epicormic meristems (Burrows et al., 2003; Fink, 1984), epicormic strands (Burrows, 2002), "embedded latitudinal suppressed buds" (Aloni and Wolf, 1984), bud clusters and burls (Fontaine et al., 2004; Kauppi et al., 1987; Stone and Cornwell, 1968), picots (Fontaine et al., 2004), spheroblasts (Fink, 1980) and lignotubers (Del Tredici, 2001).

This general and likely still incomplete census of epicormics is very useful in characterising sprouting ability of species (Del Tredici, 2001). It could be more efficient if it took into account all the types present in a given species, and replaced them in the development stages and tree parts where they emerge (Del Tredici, 2001). Our study focused on Quercus petraea since (1) $Q$. petraea is considered as a strong "sprouter" as most Quercus species (Rey-Lescure, 1982) and (2) we have studied epicormic ontogeny on $Q$. petraea trunks for the last 15 years (Colin et al., 2008, 2009; Fontaine et al., 1998, 1999, 2001, 2004), in complement to Spiecker's works (1991). The observed epicormics are buds, shoots, picots, bud clusters and burls. These different types or classes do not exist in the same proportions in all developmental stages of trees: 
buds characterise very young stages after axillary buds setting (Fontaine et al., 2001), short epicormic shoots are present in young stands (Colin et al., 2008), burls can be found on mature trees only (Fontaine et al., 2004). Epicormic buds were tallied by a few authors (Smith, 1966) and by ourselves using the epicormic potential as the number of epicormic buds that a stem segment, for instance a 1-meter-long one, bears (Fontaine et al., 2001). This descriptor currently allows a very thorough investigation of bud demography, mainly in the first years (10 $20 \mathrm{y}$ ) of tree life. However after about $20 \mathrm{y}$, the proportions of other epicormics increase.

The quantification of epicormics and the testing of the effect of various treatments have been completed mainly for epicormic shoots. To our knowledge, only two studies surveyed pre- and post-treatment epicormic shoots (O'Hara and Valappil, 2000; Wahlenberg, 1950). By taking into account epicormic buds present before thinning, Wignall and Browning (1988) showed that thinning does not change epicormic shoot emergence. Trimble and Smith (1970) studied the effect of harvest-cut openings simultaneously on buds, bud clusters and epicormic shoots, borne by border trees. To our knowledge all epicormic types present simultaneously at different developmental stages have never been quantified nor have their transformations after environmental disturbance been assessed. We assume that the use of the epicormic composition will allow a better understanding of the effect of environmental changes, especially those induced by thinnings.

This paper shows first that epicormic composition is a relevant tool allowing a finer analysis of all types of epicormics on trunks of $Q$. petraea at successive developmental stages. Second, this tool was tested by comparing the effect of various environmental changes on epicormic dynamics. Contrasted intensities of thinning were tested at three different stand ages and used as surrogates for environmental changes. By using the epicormic composition we tested the two following hypotheses. (1) Epicormic shoots emerge especially from buds predominantly present at a given developmental stage: isolated buds, bud clusters or buds within burls. Complementarily, persistent epicormic shoots, either short or long and branched, are expected to reinforce their development thanks to the burst of the buds they bear (Colin et al., 2008; Spiecker, 1991; Yokoi and Yamaguchi, 1996). (2) Upper boles bear younger epicormic composition and a higher proportion of epicormic shoots.

\section{MATERIAL AND METHODS}

This experiment took place in the compartments $62 / 63,317$ and 324 of the French oak forest of Tronçais $\left(02^{\circ} 41^{\prime} 36^{\prime \prime} \mathrm{E}\right.$, $\left.46^{\circ} 39^{\prime} 36^{\prime \prime} \mathrm{N}\right)$. Soils are mainly sandy with more or less clay or silt. The bedrock is composed of sand and clays said of "Bourbonnais"; the sand has been often transformed into sandstone. The climate is characteristic of the Loire region, with a general continental trend with strong oceanic influences; average annual temperature was $10.4{ }^{\circ} \mathrm{C}$ with precipitation of $700 \mathrm{~mm}$ at the western edge and slightly more than $800 \mathrm{~mm}$ at the eastern edge of the forest. Climate and soils were adequate for oak culture.

The silvicultural experiment was installed in 1996 by thinning according to different intensities in plots previously all at "stem exclusion stage" (Oliver and Larson, 1996 and Oliver, 1997 in Johnson et al., 2002). According to Daniel et al. (1979), plots abbreviated by "LS" belonged to "large saplings" stage, other plots belonged to "small poles" stage with the youngest abbreviated by "YP" and the oldest abbreviated by "OP" (Tab. I, Fig. 1). Plots at "Large Saplings" and "Old Small Poles" stages were located on good to very good sites (productivity ranging from 5 to $6.5 \mathrm{~m}^{3} / \mathrm{ha} /$ year) with $Q$. petraea dominant and also Fagus sylvatica, Prunus avium, Tilia cordata and Acer pseudoplatanus. In plots at "Young Small Poles" stage, soil was of slightly lower fertilility and more acid (with productivity ranging from 4 to $5 \mathrm{~m}^{3} / \mathrm{ha} / \mathrm{an}$ ) with $Q$. petraea dominant and Fagus sylvatica, Acer pseudoplatanus, Betula verrucosa, Castanea sativa, Sorbus terminalis and the fern Pteridium aquilinum.

For each stage, a control plot was identified as a plot on which no silvicultural operation had been applied either at the time of the installation or after it. The other treatments were different intensities of thinning quantified in terms of changes, before and after experiment installation, on the following variables: relative density index Rdi (Dhôte, 1997), stand density and basal area (Tab. I). Rdi values after thinning operated in year 1996 indexed the treatments.

Nine of these scenarios were selected for an epicormic assessment made in 2002 (Fig. 1). Table I provides the main characteristics of the nine corresponding plots and the average values of the usual tree descriptors. The control plots were: LS0.81 at "Large Saplings" stage, YP0.93 at "Young Small Poles" stage and OP0.94 at "Old Small Poles" stage. It must be noticed that the relative densities have increased from 1996 after thinning to 2002. They were very close to 1 for the control plots in 2002, indicating a high level of self-thinning.

For each plot, twenty trees per plot were selected among the future crop trees, except for plot SL0.21 where only 19 trees were selected. Consequently, the resulting within-plot variability was narrow and was not assessed. Trees were described in terms of diameter at breath height (DBH), height (H), height to the lowest living branch (HLLB) and surface of crown projection and corresponding average crown diameter (Dcrown). "Lower boles" located between 0.5 and $3 \mathrm{~m}$ were described on all trees. "Upper boles" located between 3 and $6 \mathrm{~m}$ were described only on trees at "Young Small Poles" and "Old Small Poles" stages (Fig. 1). The 0.5 first meters above the collar was not considered since the covering moss prevented accurate counting of epicormics, especially of buds.

The following classes of epicormics were distinguished (Tab. II): isolated buds (abbreviation b), thin and short epicormic shoots, non-branched and less than 50-mm-long and 3-year-old (abbreviation s), isolated epicormic shoots of larger dimensions with secondary buds at their base ( $\mathrm{sb}$ ), clusters of buds (bc) and "picots" (p). Picots are small stump shoots with superimposed epicormic buds and sometimes thin epicormic shoots (Fontaine et al., 2004). Bud clusters could comprise 
Table I. Main attributes of the experimental plots on which the epicormic composition has been recorded. Dominant height in $\mathrm{m}, \mathrm{Cg}$ : average girth in $\mathrm{cm}$, Density in \#stems/ha, G: basal area in $\mathrm{m}^{2} / \mathrm{ha}$. Secondary species are present in very small quantities in term of stem number and G. Numbers for oaks are thus not very different to those for all species present.

\begin{tabular}{|c|c|c|c|c|c|c|c|c|c|c|}
\hline \multirow{3}{*}{ Year } & Stand stage & \multicolumn{4}{|c|}{ Large saplings (LS) } & \multicolumn{3}{|c|}{ Young small poles (YP) } & \multicolumn{2}{|c|}{ Old small poles (OP) } \\
\hline & Treatments & $\begin{array}{c}\text { LS0.81 } \\
\text { (control) }\end{array}$ & LS0.60 & LS0.37 & $\bar{L}$ LS0.21 & $\begin{array}{r}\text { YP0.93 } \\
\text { (control) }\end{array}$ & YP0.41 & YP0.23 & $\begin{array}{r}\text { OP0.94 } \\
\text { (control) }\end{array}$ & OP0.54 \\
\hline & Compartments & \multicolumn{4}{|c|}{324} & \multicolumn{3}{|c|}{62 and 63} & \multicolumn{2}{|c|}{317} \\
\hline \multirow{7}{*}{1996} & Dominant height & 8.2 & 7.4 & 8.4 & 7 & 11.6 & 11.3 & 12 & 18 & 17.4 \\
\hline & $\mathrm{Cg}$ oak before release & 11.6 & 13.0 & 11.4 & 11.4 & 21.5 & 21.6 & 23.5 & 39.3 & 38.5 \\
\hline & Cg oak after release & 11.6 & 12.7 & 14.7 & 17.9 & 21.5 & 29.6 & 33.4 & 39.3 & 47.7 \\
\hline & $\mathrm{G}$ of oak before release & 16.05 & 14.60 & 14.91 & 15.34 & 22.36 & 24.05 & 22.73 & 27.02 & 27.58 \\
\hline & $\mathrm{G}$ of oak after release & 16.05 & 12.33 & 7.81 & 4.80 & 22.36 & 10.79 & 6.24 & 27.02 & 16.38 \\
\hline & Rdi of oak before release & 0.81 & 0.71 & 0.750 & 0.77 & 0.93 & 1.00 & 0.92 & 0.94 & 0.97 \\
\hline & Rdi of oak after release & 0.81 & 0.60 & 0.37 & 0.21 & 0.93 & 0.41 & 0.23 & 0.94 & 0.54 \\
\hline 2002 & Dominant height & 10.0 & 8.87 & 10.11 & 8.81 & 13.95 & 13.76 & 13.73 & 19.09 & 18.82 \\
\hline
\end{tabular}

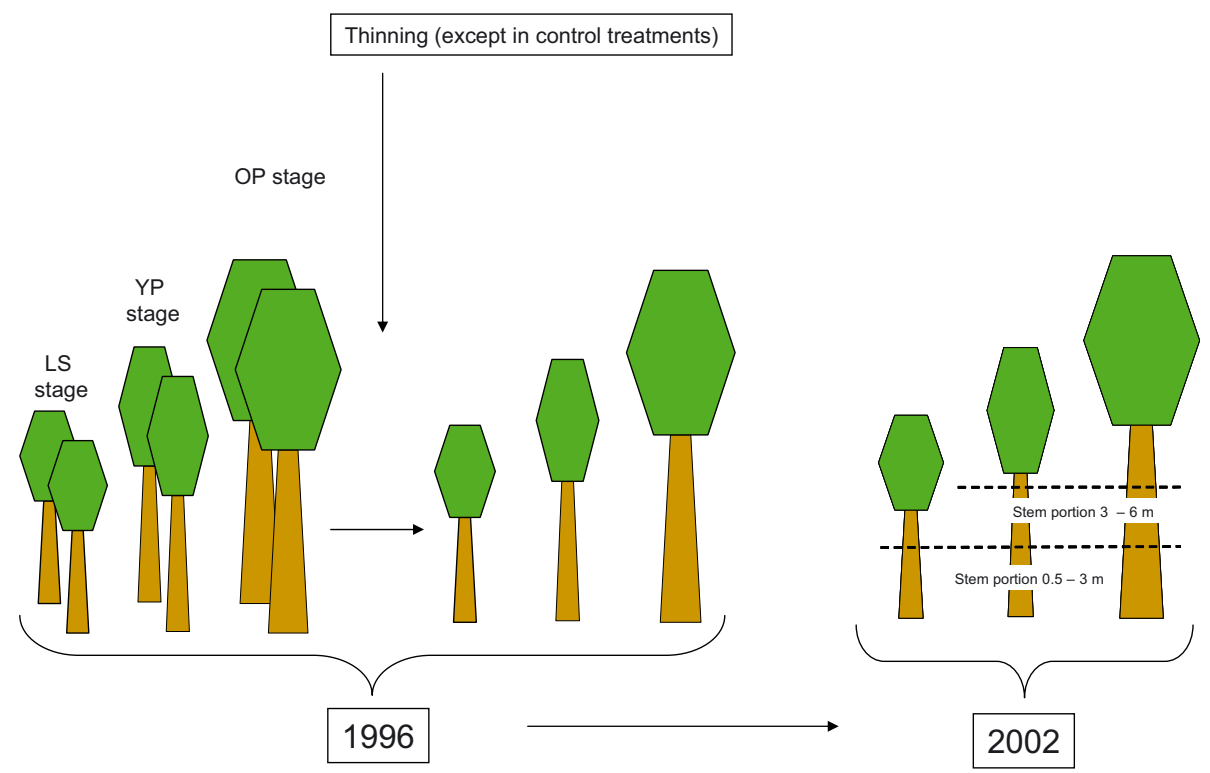

Figure 1. Schema of the epicormic experiment. In year 1996 experimental thinnings were operated in plots at "Large Saplings" (LS), "Young Small Poles" (YP) and "Old Small Poles" (OP) stages. The observation of the epicormic composition was made in 2002, on the 0.5-3 m lower and 3-6 m upper boles. (For a color version of this figure, please consult www.afs-journal.org)

theoretically from two to several buds, often less than five. The exact number was unfortunately not recorded.

We defined the epicormic composition as the arrangement of all epicormics present in various classes; we quantified it by both the total frequency of epicormics per meter and proportion of each class. The epicormic composition was basically a tree parameter but we obtained also treatment composition by gathering frequencies in each epicormic class for all trees belonging to the same treatment. Although epicormic composition was available at tree scale, effects of dimensions and dimension increments of individual trees have not been considered here.

Epicormic ontogeny was specifically defined as the course of development of epicormics, including their possible transformations from one class to others (for instance bud developing into epicormic shoots, bud clusters originating from bud branching... ). This course leads to evolving importance of the various epicormic classes accompanying the general development of the bearing trees. This course was characterized in this paper by comparing epicormic compositions of groups of trees 
Table II. Epicormic types entering the definition of epicormic composition. (For a color version of this figure, please consult www.afs-journal.org.)

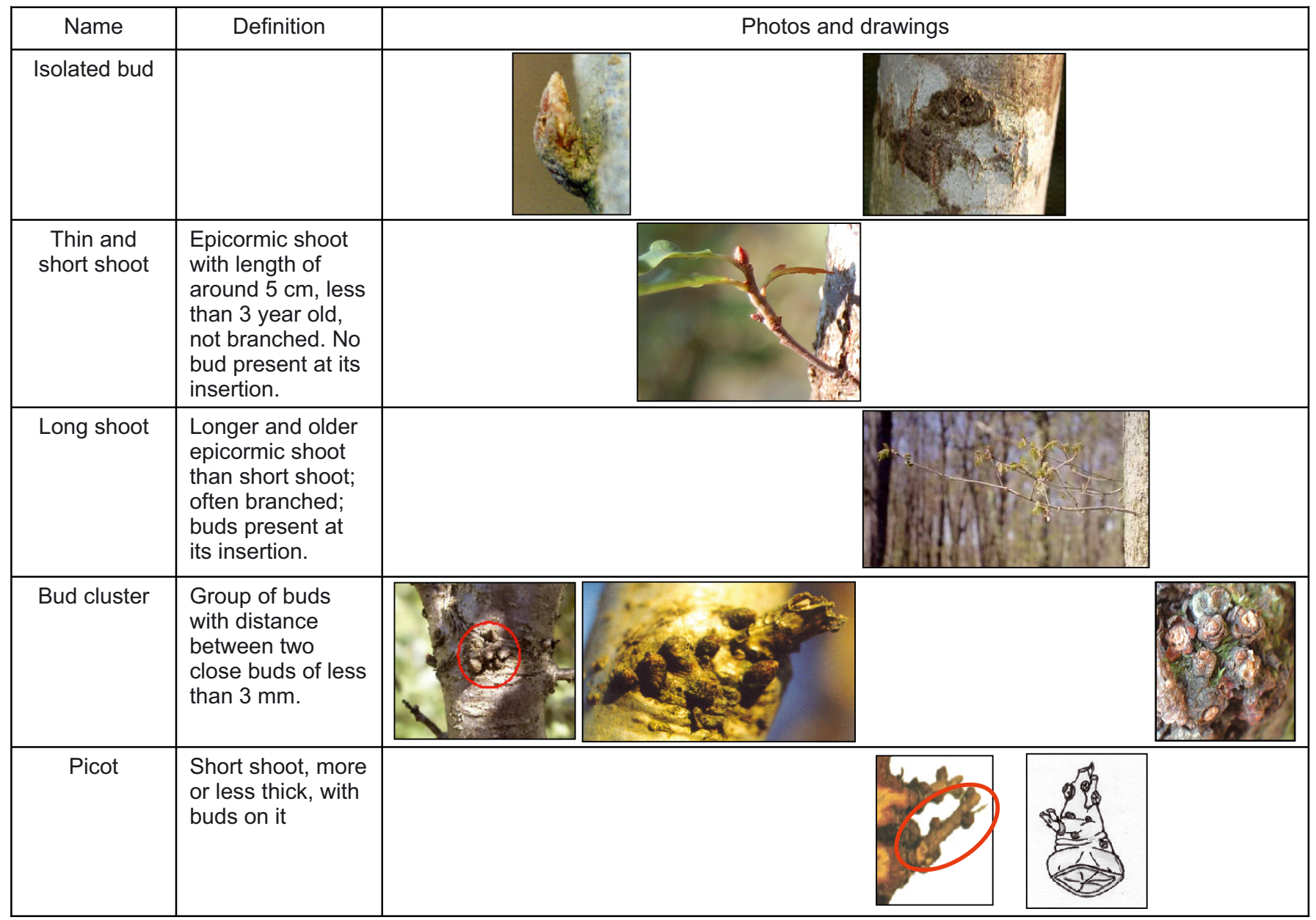

at different stand stages and also by comparing lower and upper boles. Assuming that the hypothesis usually referred to as "substituting space for time" was confirmed (what is observed on trees at different stand stages and in different plots is what can be observed over time when we follow the same population), the epicormic ontogeny was assessed by comparing the control plots of the different stand ages.

Statistical analysis and plots were made thanks to SAS software release 9.1 (SAS Institute Inc., Cary, NC, USA). Boxplots were obtained through procedure PROC BOXPLOT with statement boxstyle $=$ schematic. Analysis of variance of the total frequency of epicormics per meter was performed with procedure PROC GENMOD testing the treatment effect by the "contrast" methodology. Comparisons of epicormic compositions between treatments were carried out based on proportions calculated

- globally by treatment and bole within a developmental stage, and by using the procedure PROC FREQ and Chisquare tests;

- individually by tree and bole within a treatment; comparisons of treatments were completed by using the procedure
PROC LOGISTIC with link function glogit (since the variable epicormic type was nominal with 5 values) and the "contrast" methodology which returned $P$-values (abbreviation $\mathrm{P}$ ) of Chi-square tests.

We did the same for comparing proportions of control plots in the different developmental stages and also for comparing upper bole composition for a given stage and lower bole composition for the previous stage.

Since all comparisons displayed significant differences with $\mathrm{P}$ less than 0.001 , likely due to the high number of observations, we focus on the clearly visible differences or similarities.

\section{RESULTS}

\subsection{Characteristics of the sample trees}

Figures 2A to 2D display the distributions of the main attributes of the sample trees. A clear increase from "Large Saplings" to "Old Small Poles" stages as well as from large 

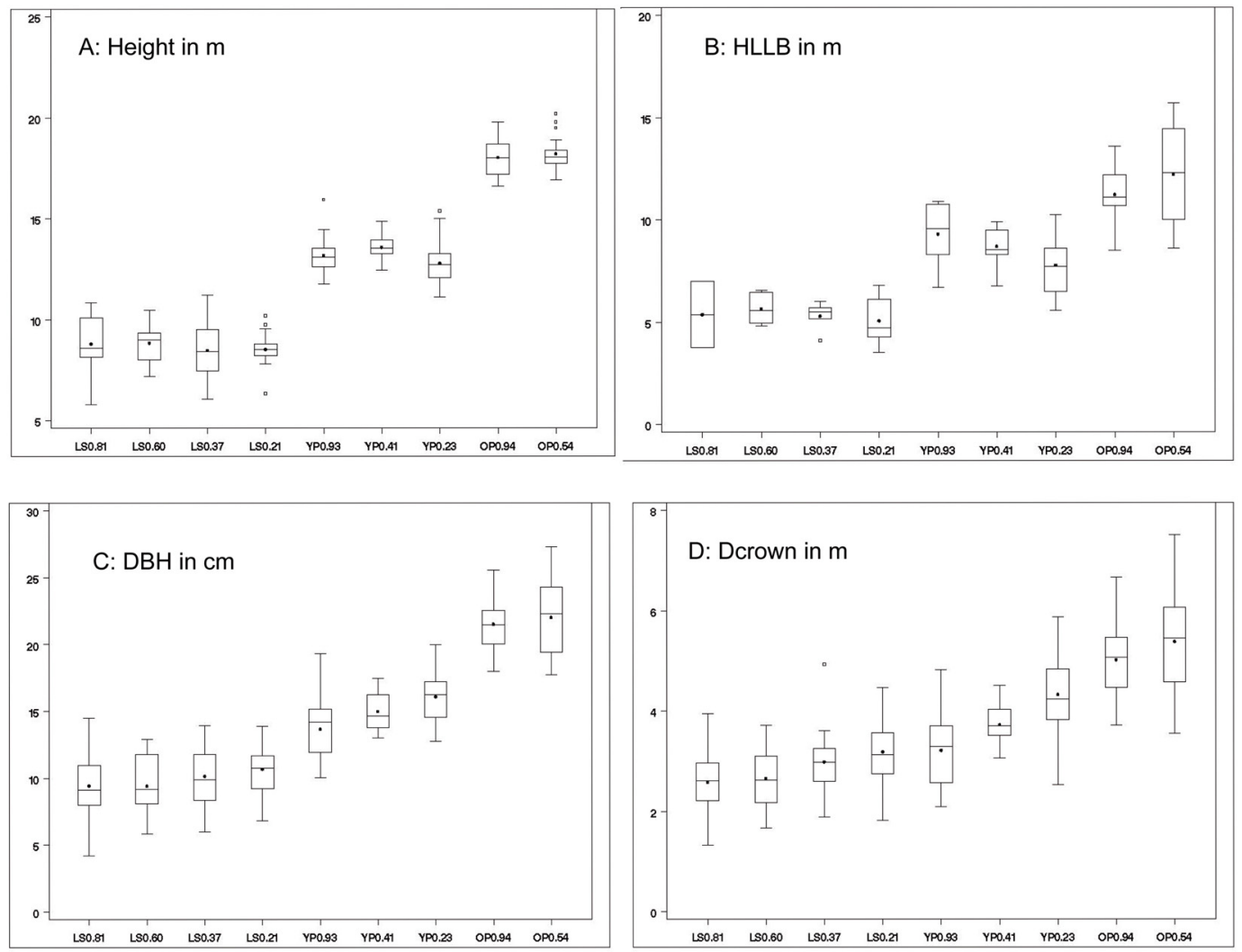

Total frequency of epicormics per meter
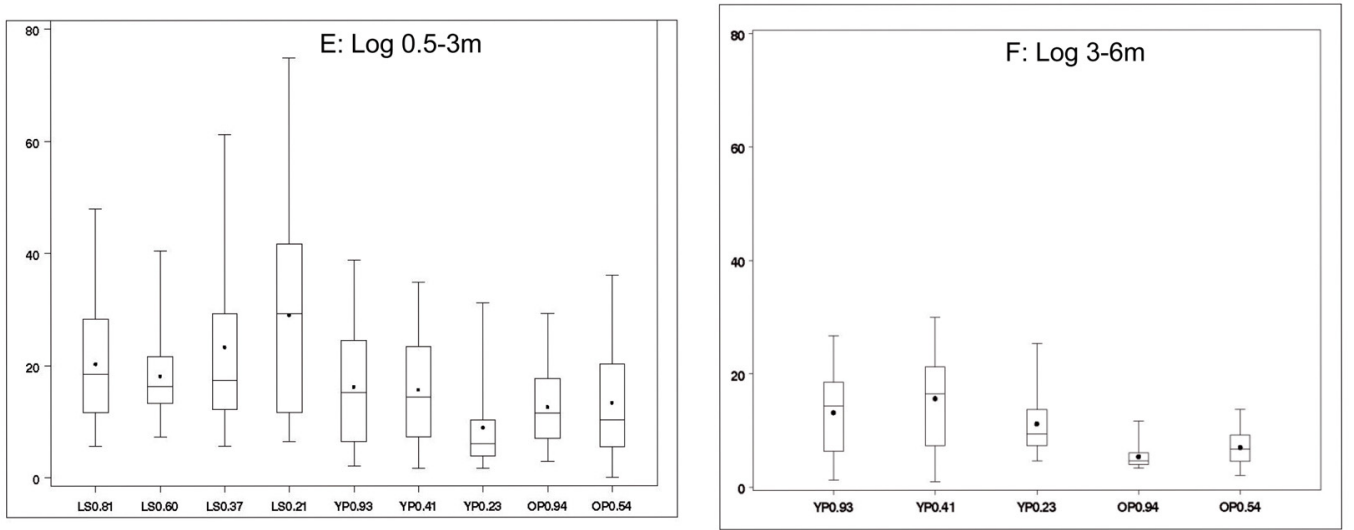

Figure 2. Main tree attributes (A: height in meter, B: height to the lowest living branch in meter, C: DBH in cm, D: mean diameter of crown projection (Dcrown) in meter) and total frequencies of epicormics displayed per trunk meter on boles $0.5-3 \mathrm{~m}(\mathrm{E})$ and 3-6 $\mathrm{m}(\mathrm{F})$.

to small Rdi was observed for H, DBH, Dcrown and less evidently HLLB. The thinning effect was most visible in "Young Small Poles" stage for both DBH and Dcrown.

\subsection{Total frequencies of epicormics}

On lower bole (Fig. 2E), a general decreasing trend appeared, although not significant, according to: "Large Saplings" > "Young Small Poles" > "Old Small Poles" stages.
For all stages and treatments the average frequencies per meter varied between 8 (YP0.23) and 30 (LS0.21). Analyses of variance made within each stage showed no significant thinning effect at both "Large Saplings" $(P=0.08)$ and "Old Small Poles" $(P=0.80)$ stages. Conversely, a significant effect appeared at "Young Small Poles" stage $(P=0.03)$ with YP0.23 and YP0.93 significantly different on the one hand $(P=0.02)$ and YP0.23 and YP0.41 significantly different on the other hand $(P=0.03)$. YP0.23 had a particularly small frequency. 
Figure $2 \mathrm{~F}$ shows that there were slightly less epicormics on the upper bole (between around 20 in OP0.94 and 50 in YP0.41, meaning between 7 and 17 per meter) than on the lower bole. No difference was detected neither at "Young Small Poles" stage $(P=0.18)$ nor at "Old Small Poles" stage $(P=0.07)$.

\subsection{Composition of lower bole at each stage (Fig. 3A)}

At "Large Saplings" stage, we observed that the differences in epicormic composition between the 3 treatments LS0.81, LS0.60 and LS0.37, although significant, were not very large. We obtained the following average proportions: buds: $30 \%$, bud clusters: $26 \%$, thin shoots: $31 \%$, shoots with buds: $6 \%$ and picots: $7 \%$. In addition, when the density reached 0.21 , the proportion of shoots with buds increased strongly $(20 \%)$ while the proportion of all other types decreased slightly. Besides these strong trends, a relatively large proportion of buds in LS0.60 and of picots in LS0.37 could be observed compared to the other treatments.

At "Young Small Poles" stage, there was a strong increase from control to YP0.23 of the proportions of shoot with buds. Proportions of bud clusters decreased to a lesser extend especially between YP0.41 and YP0.23. Proportions of both picots and shoots were quite stable while a slight decrease of buds could be observed from YP0.41.

At "Old Small Poles" stage, there was a high proportion of bud clusters (50\%) and of picots (28 and 14\%). Proportion of shoots with buds increased 3 -fold between control and OP0.54, proportion of shoots increased twice while proportion of picots was divided by two. Besides these trends, a stability of bud proportions (11\%) and a slight decrease of bud cluster proportions could be noted.

When comparing the controls at the different stages (Fig. 3A), we observed that increasing age led to a decrease of bud proportions especially between "Large Saplings" and "Young Small Poles" stages (29 to 15-11\%) and of thin shoot proportions especially between "Young Small Poles" and "Old Small Poles" stages (21-32 to 8\%). A parallel increase of bud cluster proportions especially between "Large Saplings" and "Young Small Poles" stages occurred (28 to 50-58\%). Proportions of picots increased also strongly since they reached $28 \%$, i.e. approximately 5 -fold the proportion at "Young Small Poles" stage.

\subsection{Composition of upper bole 3-6 $\mathrm{m}$ at each stage (Fig. 3B)}

At "Young Small Poles" stage and according to the thinning intensities, the increase of the proportion of shoots with buds was the strongest (7-fold) while proportions of both buds and thin shoots decreased strongly (10- and 2-fold respectively). Proportions of picots and bud clusters were quite stable.

At "Old Small Poles" stage, we observed that thinning led to a decrease of the proportion of bud clusters and a strong increase of the proportion of shoots with buds (4-fold).
When comparing the controls at both "Young Small Poles" and "Old Small Poles" stages (Fig. 3B), we could observe that the proportion of shoots with buds remained stable from "Young Small Poles" to "Old Small Poles" stages, while proportions of buds (20\% to $14 \%$ ) as well as of shoots (40 to $32 \%$ ) decreased. By contrast, proportions of bud clusters increased (32 to $44 \%$ ) as well as proportions of picots.

Comparison of the upper bole at a given stage with the lower bole at the previous stage (Figs. 3A and 3B) showed that compositions on bole " $0.5-3$ " $\mathrm{m}$ at a given stage corresponded approximately to compositions on upper bole at the next stage.

Comparison of the two boles in controls at each stage (Figs. 3A and 3B) showed that at "Young Small Poles" stage, lower bole had a larger proportion of bud clusters (58 versus $32 \%$ ) and a smaller proportion of thin shoots (21-versus $40 \%$ ) than upper bole. At "Old Small Poles" stage, lower bole had a smaller proportion of thin shoots (32 versus $8 \%$ ) and a larger proportion of picots (28 versus $4 \%$ ).

\section{DISCUSSION}

\subsection{Epicormic composition}

In this paper, by observing the changes in epicormic composition at 3 stand stages, we were able to highlight several ontogenetic trends summarized hereafter. In addition, by observing the changes of the epicormic composition following contrasted stand thinnings, we were able to assess their impacts on epicormic ontogeny. The epicormic composition appeared thus to be a relevant tool to quantify the epicormic ontogeny and its modulation by thinning. It must be noticed that we defined strictly the epicormic composition according to our objectives and the epicormic types present on sessile oak at the stand stages sampled. In fact, the definition of the epicormic composition can be adjusted according to the different epicormic types present on every species, and even for a given species by grouping or separating different epicormic classes depending on the objective of the study and the stand stages sampled.

\subsection{Epicormic ontogeny}

Among all axillary buds set on the elongated stem, at leaf or scale base, several become epicormic (Fontaine et al., 2001). Well-developed axillary buds as well as sequential shoots may bear secondary epicormic buds at their base (Colin et al., 2009; Hartig 1878). Buds of primary or secondary origin can (1) develop into epicormic shoots, (2) remain as buds or (3) branch to form bud clusters (Fontaine et al., 1999; Spiecker, 1991). Epicormic shoots can partially fall and become picots (Fontaine et al., 2001). Bud clusters with short shoots, picots or remnants of branches may gather to form burls (Stone and Cornwell, 1968) or cushion-like formations.

The general trends of epicormic ontogeny lead to various epicormic compositions on oak trunks. Our control plots gave us insights into this ontogeny independently of silvicultural 
(B)

(A)

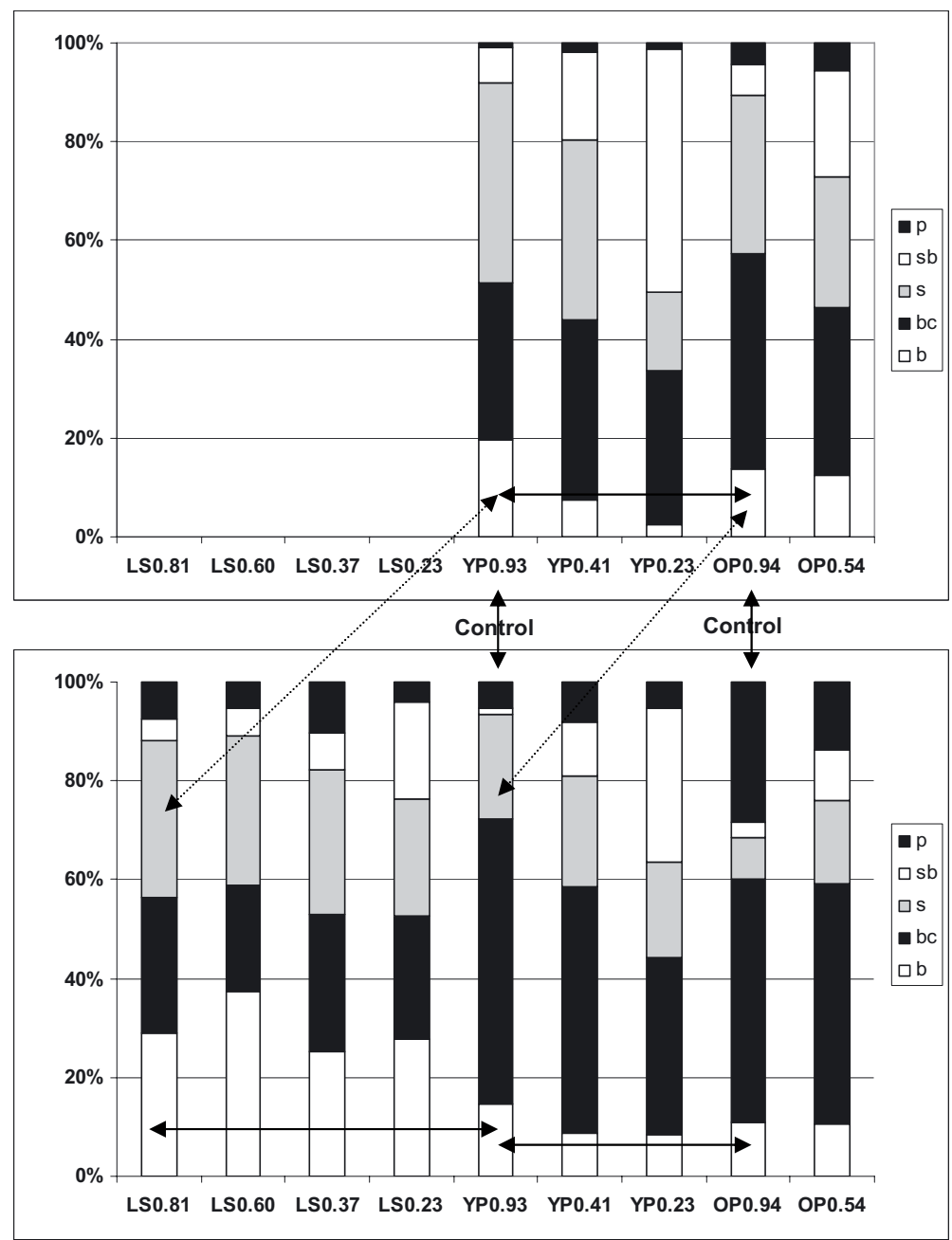

Figure 3. Epicormic compositions at "Large Saplings" stages (LS0.21 to LS0.81), "Young Small Poles" stages (YP0.23 to YP0.93) and "Old Small Plots" stages (OP0.54 and OP0.94) on logs 0.5-3 m (A) and 3-6 m (B). Vertical arrows join compositions of lower and upper boles of the same control plot. Horizontal arrows join compositions of control plots of successive stand stages. Oblique arrows join compositions of lower and upper boles of the next stand stage.

handling. Lower boles at "Large Saplings" stage bear mainly buds, short epicormic shoots and bud clusters. They bear essentially the same types of epicormics than those at "Young Small Poles" stage but the proportions changed: more bud clusters and less epicormic buds and short epicormic shoots are found at this latter stage. We thus hypothesize that on the lower bole of a tree in a non disturbed stand there is a transformation of buds and short epicormic shoots into bud clusters, (1) either by direct branching of buds producing daughter-buds without developing into shoots, as reported by Fink (1983) and Spiecker (1991), or (2) from buds set at the base of epicormic shoots. These latter buds persist while the epicormic shoots bearing them die and fall due to insufficient light.

Lower boles at "Old Small Poles" stage bear mostly bud clusters and picots. Bud clusters are numerous owing to the fact that bud clusters still present at "Young Small Poles" stage have accumulated. The accumulation of picots is explained by the partial shedding mainly of short epicormic shoots, secon- darily of rare still existing thin sequential branches and at last by the transformation of long buds bearing buds at their base. This accumulation is possible thanks to the relative persistence of the picots (Fontaine et al., 2004).

These ontogenic trends were confirmed when considering the different control plots and both lower and upper boles:

- at a given stage, epicormic compositions on upper boles are younger than epicormic composition on lower boles;

- an epicormic composition observed on the lower bole on trees at "Large Saplings" stage can be observed on the upper bole at "Young Small Poles" stage as well; equivalently an epicormic composition observed at the lower bole on trees at "Young Small Poles" stage can be observed at the upper bole at "Old Small Poles" stage as well.

Our second hypothesis was confirmed: the higher a bole is located, the more recently formed the epicormic composition it bears 


\subsection{Effects of thinnings}

Our results showed that epicormic long shoots develop from epicormic types the most present at each stage: thin shoots, buds and bud clusters at "Large Saplings" stage, bud clusters at "Young Small Poles" and "Old Small Poles" stages.

This is in agreement with our first hypothesis and with the literature (Colin et al., 2008; Stone and Cornwell, 1968; Trimble and Smith, 1970; Spiecker, 1991; Yokoi and Yamaguchi, 1996). In hardwoods, Howell and Nix (2002) showed also that according to the thinning intensity, the number of epicormic sprouts could increase 2- or 3-fold compared to control. On the contrary, some authors reported that thinning does not increase the number of epicormic shoots but mainly their size (Hibbs et al., 1989), which partly includes the transition from thin and short shoots to long shoots with buds. More light permits a higher development once buds have burst into epicormic shoots ( Il'Yushenko and Romanovskij, 2000; Spiecker, 1991; Yokoi and Yamaguchi, 1996). At "Large Saplings" stage the emergence of long epicormic shoots essentially occurred below $R d i=0.37$. At "Young Small Poles" and "Old Small Poles" stages, the emergence of epicormic shoots was more continuous with decreasing $R d i$.

Concerning the contribution of the picots, we deduce that it is preferentially the type "picots originating from long epicormic buds bearing secondary buds" that have contributed the most to epicormic shoots emergence.

The upper boles appeared more reactive tho thinnings since more epicormic shoots emerge on them compared to lower boles. This is in agreement with our second hypothesis.

\subsection{Silvicultural outcomes}

In the light of our experiment, we can provide general advice, though they need to be validated and refined in other stand situations.

Thinning at "Large Saplings" stage can be processed down to relative densities of $R d i=0.37$ without risk of epicormic shoot emergence. Below this density epicormic sprouting may occur. This result must be combined with current silvicultural advice which do not favour costly operations in the young stands except to install silvicultural paths.

The "Young Small Poles" stage is a very decisive stage since current silvicultural advice proposes scenarios with the first thinning operated when oak trees are 12-18 $\mathrm{m}$ tall (Sardin, 2008). A trunk portion free of living branches is then $4-6 \mathrm{~m}$ long (Tab. I) since past high stand densities have favoured branch pruning. In case of higher thinning intensities, natural pruning can be cancelled since new epicormic shoots can emerge. At this stage, our results show clearly a continuous and negative trend between Rdi values reflecting thinning intensity and epicormic shoot emergence. The balance between relevant thinning and low epicormic sprouting has to be defined by both foresters and scientists.

This trend observed at "Young Small Poles" stage is also present to a lesser extend at "Old Small Poles" stage although the intensity corresponding to around $\mathrm{Rdi}=0.25$ has not been tested.

In general, the upper boles are more reactive than the lower boles. This leads to the practical difficulty to obtain $6 \mathrm{~m}$ long boles free of epicormic shoots.

The following can be suggested:

- operate light but frequent crop tree thinnings;

- maintain an understorey of ligneous vegetation, enabling the lateral spread of the crown but at the same time sheltering the branch free part of the trunks;

- carefully select crop trees; the selection must be based on a thorough inspection of the trunk in order to detect the few discreet epicormic types (buds, bud clusters); this selection must start early when trees are around 30 years old and must be completed in at least two steps, the first dedicated to bud clusters, the second to both picots and bud clusters.

Acknowledgements: This study was supported by the State Forest Service "Office National des Forêts" (ONF) through successive research contracts. Fruitful discussions especially with Pierre Duplat, Myriam Legay, Patrice Mangin-Lecreux, Claudine Richter and Thomas Cordonnier in ONF R\&D in Fontainebleau and Pascal Jarret in ONF Orléans allowed this study. We will also particularly thank the technical staff who helped in installing and monitoring the experiment and collecting data, especially Daniel Rittié and Sébastien Daviller. We wish to thank Roswitha Judor and Jean-Claude Péguet in INRA Versailles for translations of German papers in French; and Sylvie Ricord for English corrections. We would thank also Holger Wernsdörfer and Mathieu Fortin for helping us in refining the concept of epicormic composition.

\section{REFERENCES}

Aloni R. and Wolf A., 1984. Suppressed buds embedded in the bark across the bole and the occurrence of their circular vessels in Ficus religiosa. Am. J. Bot. 71: 1060-1066.

Ashton P.M.S., Lowe J.S., and Larson B.C., 1990. Some evidence for the cause of epicormic sprouting in blue mahoe (Hibiscus elatus SW.) in the moist limestone region of Puerto Rico. J. Trop. For. Sci. 3: $123-130$.

Barthélémy D. and Caraglio Y., 2007. Plant architecture: a dynamic, multilevel and comprehensive approach to plant form, structure and ontogeny. Ann. Bot. 99: 375-407.

Belligham P.J. and Sparrow A.D., 2000. Resprouting as a life history strategy in woody plant communities. Oikos 89: 409-416.

Bryan J.A. and Lanner R.M., 1981. Epicormic branching in Rocky Mountain Douglas-fir. Can. J. For. Res. 11: 190-199.

Burrows G.E., 2002. Epicormic strand structure in Angophora, Eucalyptus and Lopostemon (Myrtaceae)-implications for fire resistance and recovery. New Phytol. 153: 111-131.

Burrows G.E., Offord C.A., Meagher P.F., and Ashton K., 2003. Axillary Meristems and the development of Epicormic buds in Wollemi Pine (Wollemia nobilis). Ann. Bot. 92: 835-844.

Burrows G.E., Hornby S.K., Maters D.A., Bellairs S.M., Prior L.D., and Bowman D.M.J.S., 2008. Leaf axil anatomy and bud reserves in 21 Myrtaceae species from northern Australia. Int. J. Plant. Sci. 169: 1174-1186.

Colin F., Robert N., Druelle JL., and Fontaine F., 2008. Initial spacing has little influence on transient epicormic shoots in a 20 -year-old sessile oak plantation. Ann. Sci. For. 65: 508. 
Colin F., Ducousso A., and Fontaine F., 2010. Epicormics in 13-year-old Quercus petraea: small effect of provenance and large influence of branches and growth unit limits. Ann. For. Sci. 67: 312.

Daniel T.W., Helms J.A., and Baker F.S., 1979. Principles of Silviculture. 2nd Edition, McGraw-Hill Series in Forest Resources, 500 p.

Del Tredici P., 2001. Sprouting in temperate trees: A morphological and ecological review. Bot. Rev. 67: 121-140.

Dhôte J.F., 1997. Effets des éclaircies sur le diamètre dominant dans les futaies régulières de Hêtres ou de Chêne sessile. Rev. For. Fr. XLIX: $557-578$.

Edelin C., 1977. Images de l'architecture des conifères, Ph.D. thesis, Université des Sciences et Techniques, Montpellier, 255 p.

Fink S., 1980. Anatomische Untersuchungen über das Vorkommen von Spross- und Wurzelanlagen im Stammbereich von Laub- und NadelBäumen. Allg. Forst- Jagdztg. 151: 160-182.

Fink S., 1983. The occurrence of adventitious and preventitious buds within the bark of some temperate and tropical trees. Am. J. Bot. 70: $523-542$.

Fink S., 1984. Some cases of delayed or induced development of axillary buds from persisting detached meristems in Conifers. Am. J. Bot. 71: $44-51$

Fontaine F., Druelle J.L., Clément C., Burrus M., and Audran J.C., 1998. Ontogeny of proventitious epicormic buds in Quercus petraea. I. In the five years following initiation. Trees 13: 54-62.

Fontaine F., Kiefer E., Clément C., Burrus M., and Druelle J.L., 1999. Ontogeny of proventitious epicormic buds in Quercus petraea. II. From 6 to 40 years of the tree's life. Trees 14: 83-90.

Fontaine F., Colin F., Jarret P., and Druelle J.L., 2001. Evolution of the epicormic potential on 17-year-old Quercus petraea trees: first results. Ann. For. Sci. 58: 583-592.

Fontaine F., Mothe F., Colin F., and Duplat P., 2004. Structural relationships between the epicormic formations on the trunk surface and defects induced in the wood of Quercus petraea. Trees 18: 295-306.

Hartig T., 1878. Anatomie und Physiologie der Holzpflanzen, Berlin, $412 \mathrm{p}$.

Hibbs D.E., Emmingham W.H., and Bondi M.C., 1989. Thinning red alder: effect of method and spacing. For. Sci. 35: 16-29.

Howell M. and Nix L.E., 2002. Early thinning in bottomland hardwoods. Gen. Tech. Rep. SRS-48. Asheville, NC: USDA, Forest Service, Southern Research Station, pp. 196-200.

Ishii H.. Ford E.D., and Dinnie C.E., 2002. The role of epicormic shoot production in maintaining foliage in old Pseudotsuga menziesii (Douglas-fir) trees II. Basal reiteration from older branch axes. Can. J. Bot. 80 (9): 916-926.
Johnson P.S., Shifley S.R., and Rogers R., 2002. The Ecology and Silviculture of Oaks. CABI Publishing, 503 p.

Kauppi A., Rinne P., and Ferm A., 1987. Initiation, structure and sprouting of dormant basal buds in Betula pubescens. Flora 179: 55-83.

Meadows J.S. and Burkhardt E.C., 2001. Epicormic branches affect lumber grade and value in willow oak. South. J. Appl. For. 25: 136-141.

Nicolini E., Chanson B., and Bonne F., 2001. Stem growth and epicormic branch formation in understorey beech trees (Fagus sylvatica L.). Ann. Bot. 87: 737-750.

Nicolini E., Caraglio Y., Pélissier R., Leroy C., and Roggy J.C., 2003. Epicormic Branches: a Growth Indicator for the Tropical Forest Tree, Dicorynia guianensis Amshoff (Caesalpiniaceae). Ann. Bot. 92: 97105.

O'Hara K.L. and Berrill J.B., 2009. Epicormic sprout development in pruned coast redwood: pruning severity, genotype, and sprouting characteristics. Ann. For. Sci. 66: 409.

O'Hara K.L. and Valappil N.I., 2000. Epicormic sprouting of pruned western larch. Can. J. For. Res. 30: 324-328.

Rey-Lescure E., 1982. The distribution of epicormic branches on the bole of 25 species bordering clear-cut strips. Can. J. For. Res. 12: 687698.

Sardin T., 2008. Chênaies continentales. Guide des sylvicultures, ONF Edition, Lavoisier Paris, 455 p.

Smith H.C., 1966. Epicormic branching on eight species of Appalachian hardwoods, USDA Forest Service, Research Note NE-53: 1-4.

Spiecker H., 1991. Zur Steuerung des Dickenwachstums und der Astreinigung von Trauben- und Stieleichen (Quercus petraea (Matt.) Liebl. und Quercus robur L.), Schriftenreihe der Landesforstverwaltung, Band 72, $150 \mathrm{p}$.

Stone E.L. and Cornwell S.M., 1968. Basal Bud Burls in Betula populifolia. For. Sci. 14: 64-68.

Stubbs J., 1986. Hardwood epicormic branching. Small knots but large losses. South. J. Appl. For. 10: 214-220.

Trimble G.R. and Smith H.C., 1970. Sprouting of dormant buds on border trees. USDA Forest Service Research Paper NE-179: 1-7.

Wahlenberg W.G., 1950. Epicormic branching of young yellow-poplar. J. For. 417-419.

Wignall T.A. and Browning G., 1988. The effects of stand thinning and artificial shading on epicormic bud emergence in pedunculate oak (Quercus robur L.). Forestry 61: 46-59.

Yokoi S. and Yamaguchi K., 1996. Origin of epicormic branches and effect of thinning on their development in Quercus mongolica var. Grosseserrata. J. Jpn For. Soc. 78: 169-174. 